\title{
Pemetaan Psikografis Kependudukan Untuk Kepentingan Kampanye Pilkada (Studi Kasus: Kota Cimahi)
}

\author{
MUHAMMAD GUNAWAN, SUMARNO, INDRIANAWATI
}

\author{
Jurusan Teknik Geodesi \\ FTSP - Institut Teknologi Nasional, Bandung \\ Email: mhdgunawan8@gmail.com
}

\begin{abstract}
ABSTRAK
Pemilihan kepala daerah (pilkada) memberikan kesempatan kepada masyarakat untuk memilih kepala daerahnya tanpa melalui suatu perwakilan. Dalam pelaksanaan pilkada terdapat proses kampanye yang bertujuan meyakinkan pemilih untuk memilih calon pasangan tertentu. Tujuan dari pemetaan psikografis kependudukan untuk kepentingan kampanye adalah memberikan data awal kampanye dan lokasi potensial kampanye. Penelitian ini menggunakan metode analisis statistika spasial dengan metode Global Moran's I dan Getis Ord-G terhadap data karakteristik kependudukan untuk mengetahui adanya autokorelasi spasial dan bentuk pola kluster antara unit wilayah (kelurahan) di Kota Cimahi. Berdasarkan hasil analisis statistika spasial, dapat diketahui bahwa di seluruh kelurahan Kota Cimahi, data awal kampanye yang relevan adalah data karakteristik pekerjaan dan agama. Karakteristik pendidikan relevan di seluruh kelurahan Kota Cimahi, kecuali Kelurahan Cimahi dan Karangmekar. Karakteristik usia juga relevan di seluruh kelurahan Kota Cimahi, kecuali Kelurahan Cimahi dan Pasirkaliki.
\end{abstract}

Kata kunci: kampanye, statistika spasial, autokorelasi, pola kluster

\begin{abstract}
Regional heads election (Pilkada) has given an opportunity to people for choosing their regional heads without any delegation in general election. The general election includes campaign process, which aims to select a certain candidate. In the campaign process, psychographic mapping of demography aims to give preliminary data and potential location of the campaign. This research has used spatial statistical analysis using Global Moran's I and Getis Ord-G methods for analysing demographic characteristics. The methods aim to know spatial autocorrelation as well as cluster pattern between villages in Cimahi District. The analysis result shows the relevant characteristics in all Cimahi villages are job and religion. Meanwhile, education characteristic is relevant in all villages Cimahi, except Cimahi and Karangmekar villages. Age characteristic is also relevant in all villages Cimahi, except Cimahi and Pasirkaliki villages.
\end{abstract}

Keywords: campaign, spatial statistic, autocorelation, cluster pattern 


\section{PENDAHULUAN}

Otonomi daerah atau desentralisasi merupakan penyerahan wewenang tertentu kepada suatu daerah oleh pemerintah pusat (Hoessein, 1997 dalam Ikhsan, 2016). Implementasi otonomi daerah di Indonesia diwujudkan dalam bentuk pemilihan kepala daerah secara langsung. Desentralisasi politik tersebut tercantum dalam Undang-Undang Republik Indonesia Nomor 8 Tahun 2015 tentang perubahan atas Undang-Undang Republik Indonesia Nomor 1 Tahun 2015 tentang penetapan peraturan pemerintah pengganti Undang-Undang Republik Indonesia Nomor 1 Tahun 2014 Tentang Pemilihan Gubernur, Bupati, dan Walikota Menjadi Undang-Undang, yaitu dalam pasal 1 ayat 1 , dijelaskan bahwa pemilihan gubernur, bupati, dan walikota yang selanjutnya disebut pemilihan adalah pelaksanaan kedaulatan rakyat di wilayah provinsi dan kabupaten/kota untuk memilih gubernur, bupati, dan walikota secara langsung dan demokratis (Republik Indonesia, 2015).

Pemilihan kepala daerah (pilkada) memberikan ruang yang luas bagi partisipasi politik masyarakat untuk menentukan kepala daerah sesuai dengan aspirasi dan kebutuhan di daerah masing-masing, sehingga kebijakan-kebijakan dari pemerintah dapat sesuai dengan harapan dan keinginan rakyat secara umum dan mendekatkan pemerintah kepada rakayat (Edwin dkk., 2011). Dalam pelaksanaan pilkada, masyarakat memiliki kesempatan untuk memilih kepala daerahnya tanpa melalui suatu perwakilan. Hal ini akan menciptakan keseimbangan politik karena masyarakat dapat ikut serta dalam menentukan jalannya pemerintahan dengan memilih pemimpin yang diinginkan secara bebas dan rahasia. Dalam menentukan pemimpin yang dapat memperjuangkan aspirasi dan memenuhi kepentingan rakyat, masyarakat harus memilih dengan penuh kesadaran dan pertimbangan.

Menurut Komisi Pemilihan Umum (KPU) dan Komite Independen Pemantauan Pemilu (KIPP) Kabupaten Sampang dalam pelaksanaan pilkada terdapat proses kampanye. Kampanye merupakan kegiatan menawarkan visi, misi, dan program pasangan calon dan/atau informasi lainya, yang bertujuan mengenalkan atau meyakinkan pemilih untuk memilih calon pasangan tertentu. Dalam kampanye terdapat beberapa kegiatan yaitu alat peraga kampanye, bahan kampanye, iklan kampanye, debat, pertemuan terbatas, pertemuan tatap muka dan dialog, serta rapat umum, yang secara keseluruhan berperan memberikan peluang kepada kandidat untuk dapat terpilih (KPU \& KIPP Kabupaten Sampang, 2015).

Agar mendapatkan materi kampanye yang tepat untuk disampaikan, diperlukan adanya data atau informasi awal untuk menganalisis potensi pemilihan terlebih dahulu. Data atau informasi tersebut bersumber dari masalah sosial kependudukan yang merupakan ketidaksesuaian antara unsur-unsur kebudayaan dan masyarakat, yang membahayakan kehidupan kelompok sosial (Soekanto, 2007). Terdapat beberapa faktor terkait masalah kependudukan yang dihadapi masyarakat secara umum, yaitu faktor ekonomi, kesehatan, pendidikan, dan kejahatan. Dalam penelitian ini akan dilakukan analisis data psikografis kependudukan (demografi) berdasarkan faktor-faktor masalah sosial yang umumnya terjadi di lingkungan masyarakat menggunakan statistika spasial.

\section{METODOLOGI}

Metodologi penelitian yang dilaksanakan dapat dilihat pada Gambar 1. Berikut penjelasan dari diagram alir metodologi penelitian yaitu:

1) Persiapan

Kegiatan yang dilakukan adalah mempersiapkan data yang diperoleh dari Direktorat Jenderal Kependudukan dan Pencatatan Sipil Kementerian Dalam Negeri berupa data 
karakteristik kependudukan dan Badan Pusat Statistik berupa data Peta Batas Administrasi Kota Cimahi.

2) Identifikasi Data

Yaitu kegiatan menelaah karakteristik informasi dari data yang telah diperoleh yang sesuai dengan tujuan penelitian yang berkaitan dengan isu-isu kampanye pada pemilihan kepala daerah.

3) Spasialisasi Data

Adalah proses mengubah data atribut menjadi data spasial, yaitu dengan melakukan penggabungan data Peta Batas Administrasi Kota Cimahi dengan data karakteristik demografi, sehingga diperoleh data spasial pemilih karakteristik pekerjaan, agama, pendidikan, dan usia.

4) Analisis Statistika Spasial

Yaitu proses menganalisis data spasial menggunakan metode statistika spasial untuk mengidentifikasi adanya autokorelasi spasial pada masing-masing dataset karakteristik demografi dan pola kluster yang terbentuk sehingga dihasilkan peta tematik lokasi potensial kampanye karakteristik usia, pendidikan, pekerjaan, dan agama.

5) Kesimpulan

Yaitu penarikan kesimpulan dari peta tematik lokasi potensial kampanye karakteristik usia, pendidikan, pekerjaan, dan agama sehingga diperoleh informasi mengenai data awal bagi kandidat calon kepala daerah dan lokasi potensial untuk dilaksanakannya kampanye.

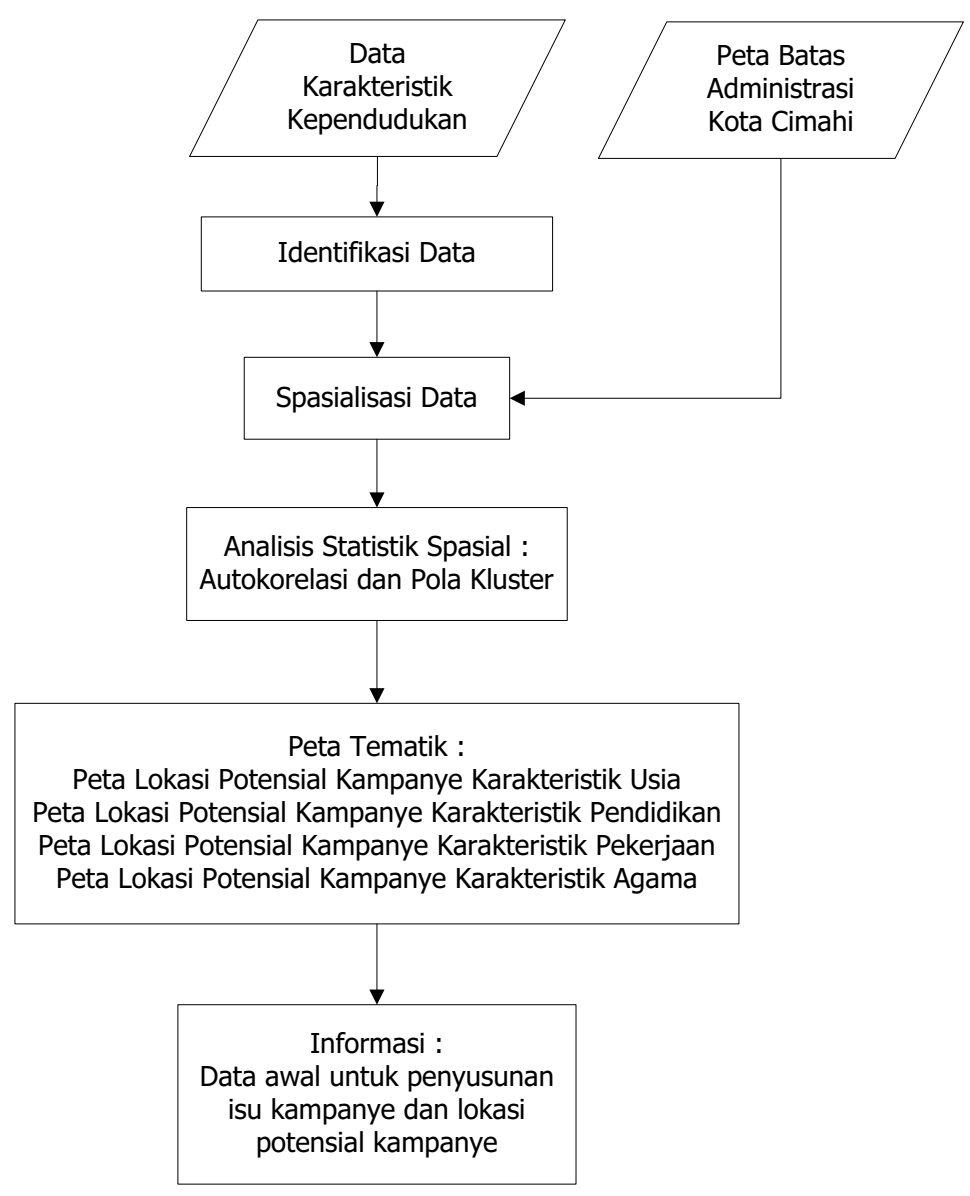

Gambar 1. Diagram Alir Metodologi Penelitian 


\section{HASIL DAN PEMBAHASAN}

\subsection{Hasil Perhitungan Autokorelasi Spasial}

Autokorelasi spasial digunakan untuk menilai dataset secara keseluruhan, apakah masingmasing objek yang didefinisikan sebagai lokasi dalam tingkat kelurahan di Kota Cimahi tersebut memiliki saling kemiripan nilai karakteristik demografis. Dengan kata lain, ada atau tidaknya autokorelasi menjelaskan hubungan kedekatan karakteristik demografis tertentu antarkelurahan di Kota Cimahi. Hasil perhitungan autokorelasi spasial untuk masing-masing dataset karakteristik demografis dapat dilihat pada Tabel 1 - Tabel 4. Dari hasil perhitungan autokorelasi dengan metode Global Moran's I, maka dapat diketahui parameter-parameter meliputi Moran's Index, nilai harapan, variansi, z-score, dan $p$-value. Parameter tersebut selanjutnya digunakan untuk uji statistik, sehingga dapat diketahui ada atau tidaknya autokorelasi dalam dataset tersebut dan bagaimana pola spasial yang terbentuk dari distribusi variabel dalam masing-masing dataset.

Tabel 1. Autokorelasi Spasial (Moran's I) Dataset Karakteristik Usia

\begin{tabular}{lccccc}
\hline \multicolumn{1}{c}{ Nilai Atribut } & Moran's Index & Nilai Harapan & Variansi & Z-Score & P-Value \\
\hline Pemula & 0,89221 & $-0,002433$ & 0,000892 & 29,95717 & 0 \\
Pemilih Tetap & 0,903615 & $-0,002433$ & 0,000892 & 30,34489 & 0 \\
Lansia & 0,824048 & $-0,002433$ & 0,000892 & 27,68938 & 0 \\
\hline
\end{tabular}

Tabel 2. Autokorelasi Spasial (Moran's I ) Dataset Karakteristik Pekerjaan

\begin{tabular}{lccccc}
\hline \multicolumn{1}{c}{ Nilai Atribut } & Moran's Index & Nilai Harapan & Variansi & Z-Score & P-Value \\
\hline Wiraswasta & 0,886712 & $-0,002433$ & 0,00089 & 29,80972 & 0 \\
Karyawan Swasta & 0,881654 & $-0,002433$ & 0,000891 & 29,62048 & 0 \\
BUMN dan BUMD & 0,852431 & $-0,002433$ & 0,00089 & 28,64472 & 0 \\
PNS, TNI, POLRI dan Pensiunan & 0,694623 & $-0,002433$ & 0,00089 & 23,36871 & 0 \\
Pedagang & 0,829743 & $-0,002433$ & 0,00089 & 27,88190 & 0 \\
Buruh & 0,848946 & $-0,002433$ & 0,00089 & 28,50813 & 0 \\
Kesehatan & 0,740994 & $-0,002433$ & 0,00088 & 24,98366 & 0 \\
Tidak Bekerja & 0,84814 & $-0,002433$ & 0,00089 & 28,49467 & 0 \\
Profesi & 0,848868 & $-0,002433$ & 0,00089 & 28,52283 & 0 \\
Pertanian & 0,882435 & $-0,002433$ & 0,00088 & 29,79622 & 0 \\
Lain-lain & 0,862733 & $-0,002433$ & 0,00089 & 28,97372 & 0 \\
\hline
\end{tabular}

Tabel 3. Autokorelasi Spasial (Moran's I) Dataset Karakteristik Pendidikan

\begin{tabular}{lccccc}
\hline \multicolumn{1}{c}{ Nilai Atribut } & Moran's Index & Nilai Harapan & Variansi & Z-Score & $\boldsymbol{P}$-Value \\
\hline Strata 3 & 0,811941 & $-0,002433$ & 0,000888 & 27,327645 & 0 \\
Strata 2 & 0,804695 & $-0,002433$ & 0,000886 & 27,119247 & 0 \\
Diploma 4 dan Strata 1 & 0,83032 & $-0,002433$ & 0,000889 & 27,933892 & 0 \\
Akademi atau Diploma 3 & 0,82607 & $-0,002433$ & 0,000888 & 27,809631 & 0 \\
Diploma 2 atau Diploma 3 & 0,802449 & $-0,002433$ & 0,00089 & 26,978534 & 0 \\
SLTA & 0,855349 & $-0,002433$ & 0,00089 & 28,747792 & 0 \\
SLTP & 0,854623 & $-0,002433$ & 0,000891 & 28,716514 & 0 \\
SD & 0,886694 & $-0,002433$ & 0,000891 & 29,78262 & 0 \\
Tidak tamat SD & 0,834413 & $-0,002433$ & 0,000892 & 28,021499 & 0 \\
\hline
\end{tabular}


Pemetaan Psikografis Kependudukan untuk Kepentingan Kampanye Pilkada

(Studi Kasus: Kota Cimahi)

Tabel 4. Autokorelasi Spasial (Moran's I) Dataset Karakteristik Agama

\begin{tabular}{lccccc}
\hline Nilai Atribut & Moran's Index & Nilai Harapan & Variansi & Z-Score & $\boldsymbol{P}$-Value \\
\hline Islam & 0,861154 & $-0,002433$ & 0,000891 & 28,929697 & 0 \\
\hline Kristen & 0,852635 & $-0,002433$ & 0,000888 & 28,686708 & 0 \\
\hline Katolik & 0,779907 & $-0,002433$ & 0,000892 & 26,199999 & 0 \\
\hline Budha & 0,886396 & $-0,002433$ & 0,00089 & 29,800624 & 0 \\
\hline Hindu & 0,739867 & $-0,002433$ & 0,000886 & 24,942279 & 0 \\
\hline Konghucu & 0,872 & $-0,002433$ & 0,000888 & 29,348556 & 0 \\
\hline Lainnya & 0,742676 & $-0,002433$ & 0,000887 & 25,017614 & 0 \\
\hline
\end{tabular}

\subsection{Hasil Perhitungan Pemusatan Pola Kluster}

Perhitungan pemusatan kluster dilakukan dengan menggunakan metode Getis-Ord G. Hasilnya berupa tampilan spasial variabel pada masing-masing karakteristik demografi. Tampilan spasial tersebut memperlihatkan tingkat unit area yang menunjukkan lokasi-lokasi pemusatan nilai yang tinggi (hot spot) dan rendah (cold spot). Contoh hasil perhitungan pemusatan kluster dapat dilihat pada Gambar 2. Perhitungan pemusatan pola kluster tersebut dilakukan berdasarkan variabel pemilih lansia. Dari hasil tersebut kemudian dapat dibentuk peta tematik lokasi potensial kampanye berdasarkan karakteristik usia pemilih.

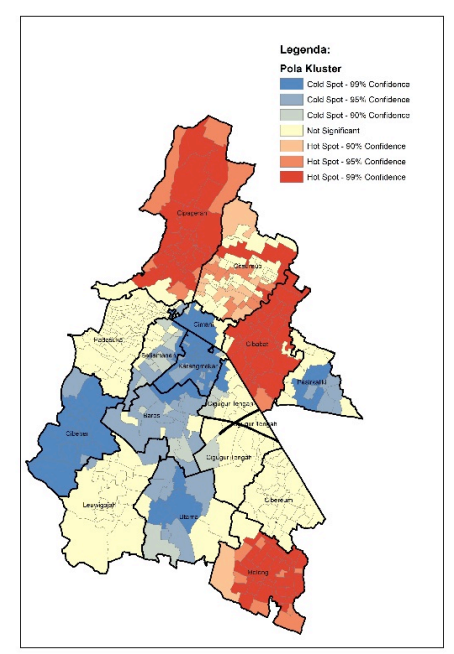

(Pemilih Lansia)

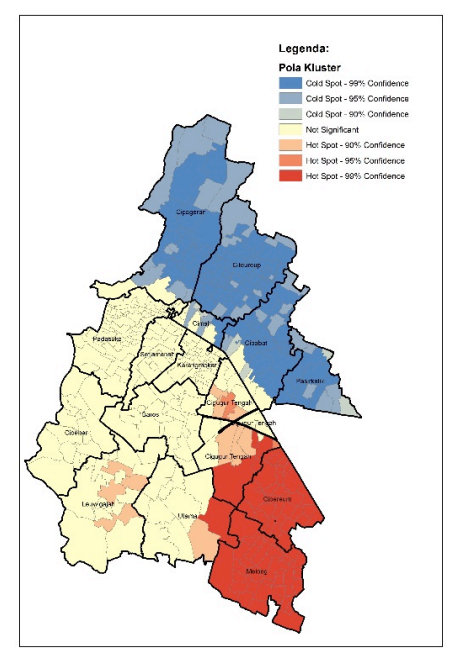

(Pemilih Tetap)

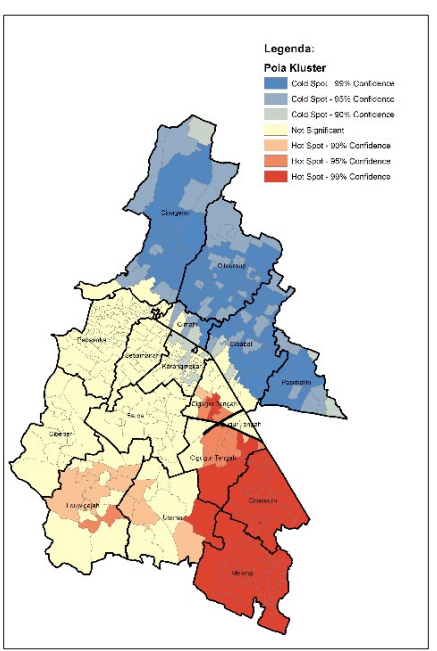

(Pemilih Pemula)

\section{Gambar 2. Analisis Kluster Lokasi Potensial Pemilih Berdasarkan Karakteristik Usia}

\subsection{Analisis}

Terkait hasil penelitian yang diperoleh selanjutnya dilakukan analisis data kependudukan, analisis hasil autokorelasi spasial, dan pola kluster.

\subsubsection{Analisis Data Kependudukan}

Data yang digunakan pada penelitian ini adalah data karakteristik demografi Kota Cimahi tahun 2014 yang diperoleh dari Direktorat Jenderal Kependudukan dan Pencatatan Sipil Kementerian Dalam Negeri. Data tersebut terdiri atas data statistik jumlah penduduk berdasarkan karakteristik demografi, yaitu pekerjaan, agama, pendidikan dan usia pemilih. Data statistik tersebut merupakan jenis data kependudukan berupa data agregat yang diperoleh dari kegiatan pendaftaran penduduk dan pencatatan sipil di Kota Cimahi. Secara 
teoritis, data agregat merupakan kumpulan data tentang peristiwa kependudukan, peristiwa penting, jenis kelamin, kelompok usia, agama, pendidikan, dan pekerjaan. Informasi yang dianalisis dari data agregat yang diperoleh adalah informasi mengenai jumlah penduduk yang berada pada wilayah administrasi tingkat kelurahan di Kota Cimahi. Informasi tersebut dianalisis secara spasial untuk mengetahui adanya hubungan kemiripan nilai antara kelurahan satu dengan yang lain. Selain itu, dilakukan analisis pola kluster yang terbentuk dari distribusi jumlah penduduk di setiap kelurahan di Kota Cimahi untuk mengetahui lokasi pemusatan jumlah penduduk yang tinggi dan jumlah penduduk yang rendah.

\subsubsection{Analisis Hasil Autokorelasi Spasial dan Pola Kluster}

Terkait hasil penelitian selanjutnya dilakukan analisis terhadap hasil perhitungan autokorelasi spasial (Global Moran's I) dan perhitungan pemusatan kluster spasial (Getis-Ord G). Analisis hasil dari proses pengolahan data dijabarkan sebagai berikut:

1) Autokorelasi Spasial (Global Moran's I)

Analisis spasial yang dilakukan pertama kali yaitu menentukan adanya autokorelasi spasial pada dataset 4 karakteristik kependudukan Kota Cimahi. Perhitungan autokorelasi spasial dengan Global Moran's I menghasilkan nilai yang disebut dengan Moran's Index. Nilai tersebut digunakan untuk mengidentifikasi variabel-variabel dataset karakteristik kependudukan pada unit wilayah administrasi kelurahan Kota Cimahi. Hasil analisis dataset karakteristik kependudukan berupa informasi apakah terdapat autokorelasi spasial dan pembentukan pola kluster (berkelompok) di dalam dataset tersebut. Hasil yang diperoleh dijelaskan sebagai berikut:

a. Dataset karakteristik usia berisikan variabel jenis pemilih yaitu jumlah pemilih tetap, pemilih pemula, dan pemilih lansia. Dari ke 3 jenis variabel tersebut masing-masing dihitung dengan Global Moran's I didapatkan kesimpulan bahwa kelurahan di Kota Cimahi saling berautokorelasi. Autokorelasi yang terbentuk merupakan autokorelasi positif yang menunjukkan adanya pola kluster di beberapa lokasi kelurahan dengan tingkat signifikansi 99\%. Sehingga hanya ada 1\% kecenderungan hasil membentuk pola yang acak (random). Korelasi yang terbentuk dapat dikatakan kuat karena hasil perhitungan Index Moran's mendekati nilai 1.

b. Dataset karakteristik pendidikan berisikan variabel tingkat pendidikan penduduk Kota Cimahi yaitu S3, S2, D4 atau S1, D3 atau akademi, D2 atau D3, SLTA, SLTP, SD, dan tidak tamat SD. Dari hasil hitungan dan uji statistik didapatkan kesimpulan bahwa untuk masing-masing variabel tersebut di setiap kelurahan di Kota Cimahi saling berautokorelasi positif yang menunjukkan adanya pola kluster dengan tingkat signifikansi $99 \%$. Sehingga hanya ada $1 \%$ kecenderungan hasil membentuk pola yang acak (random). Korelasi yang terbentuk dikatakan kuat dengan nilai Index Moran's mendekati nilai 1.

c. Dataset karakteristik pekerjaan berisikan variabel jenis-jenis pekerjaan yang dijalani oleh penduduk Kota Cimahi yaitu Wiraswasta, Karyawan Swasta, BUMN atau BUMD, PNS/TNI/POLRI/Pensiunan, Pedagang atau Perdagangan, Buruh, Kesehatan, Tidak Bekerja, Profesi, dan Pertanian. Dari hasil hitungan dan uji statistik diperoleh kesimpulan bahwa untuk masing-masing variabel tersebut di setiap kelurahan di Kota Cimahi saling berautokorelasi positif sehingga menunjukkan adanya pola kluster di beberapa lokasi kelurahan dengan tingkat signifikansi $99 \%$. Sehingga hanya ada $1 \%$ kecenderungan hasil membentuk pola yang acak (random). Korelasi yang terbentuk dikatakan kuat dengan nilai Index Moran's mendekati nilai 1.

d. Dataset karakteristik agama berisikan variabel jenis-jenis agama yang dianut oleh penduduk Kota Cimahi yaitu Islam, Kristen, Katolik, Budha, Hindu, Konghucu, dan lainnya. Dari hasil hitungan dan uji statistik diperoleh kesimpulan bahwa untuk masing-masing variabel tersebut di setiap kelurahan di Kota Cimahi saling 
berautokorelasi positif sehingga menunjukkan adanya pola kluster di beberapa lokasi kelurahan dengan tingkat signifikansi $99 \%$. Sehingga hanya ada $1 \%$ kecenderungan hasil membentuk pola yang acak (random). Korelasi yang terbentuk dikatakan kuat dengan nilai Index Moran's mendekati nilai 1.

2) Pola Kluster Spasial (Getis-Ord G)

Analisis pola kluster dilakukan menggunakan metode Getis-Ord G. Hasil perhitungan statistik diperoleh parameter $Z_{G}$ dan $P$-value. $Z$-score $G$ statistik digunakan untuk menentukan tingkat signifikansi statistik. Selain itu juga diperoleh tingkat kepercayaan masing-masing feature pada tingkatan 90\%, 95\%, dan 99\%. Contoh hasil tampilan statistik dataset karakteristik usia variabel pemilih lansia dapat dilihat pada Gambar 3.

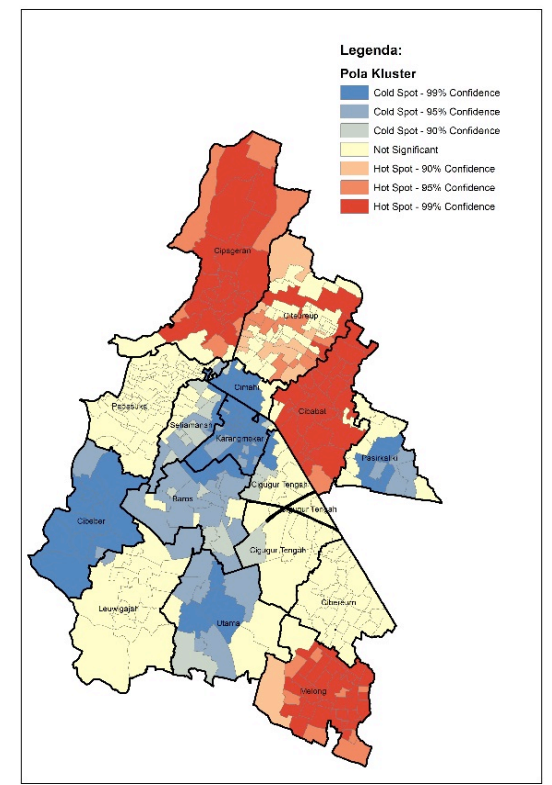

\section{Gambar 3. Contoh visualisasi pola kluster feature dataset karakteristik usia variabel} pemilih lansia pada tingkat kepercayaan $90 \%, 95 \%$ dan $99 \%$

Dari hasil tersebut dapat dilihat secara visual pola feature yang terbentuk. Pada penelitian ini digunakan tingkat kepercayaan 99\% dan taraf signifikansi sebesar 0.01 dimana kebenaran hasil yang diperoleh pada penelitian mencapai $99 \%$ dan hanya $1 \%$ kecenderungan terjadinya kesalahan. Nilai $Z_{G}$ yang tinggi dan $p$-value yang rendah pada masing-masing feature mengindikasikan pola kluster membentuk hot spot, nilai $Z_{G}$ yang rendah dibandingkan $p$-value yang tinggi pada masing-masing feature mengindikasikan pola kluster membentuk cold spot dan nilai $Z_{G}$ yang mendekati 0 (nol) mengindikasikan tidak terbentuk pola kluster (not significant). Analisis dilakukan dengan melihat nilai parameter tersebut untuk menentukan lokasi-lokasi potensial kampanye di Kota Cimahi. Sebagai contoh hasil analisis pada dataset karakteristik usia untuk variabel pemilih lansia diketahui unit wilayah yang membentuk hot spot sejumlah 3 unit, yaitu pada Kelurahan Cipageran, Cibabat, dan Melong. Unit cold spot sejumlah 4 unit, yaitu pada Kelurahan Cibeber, Karangmekar, Utama dan Pasirkaliki. Serta unit wilayah yang tidak signifikan membentuk pola kluster sejumlah 4 unit, yaitu Cibeureum, Leuwigajah, Cigugur Tengah, dan Padasuka. Dari hasil analisis tersebut diperoleh informasi sebagai berikut:

a. Pola kluster yang membentuk pemusatan hot spot menunjukan lokasi yang sangat relevan, sehingga diperoleh 3 lokasi sangat relevan.

b. Pola menyebar yang tidak signifikan untuk membentuk pemusatan nilai yang tinggi ataupun rendah menunjukan lokasi yang relevan, sehingga diperoleh 4 lokasi relevan. 
c. Pola kluster yang membentuk pemusatan cold spot menunjukan lokasi yang tidak relevan, sehingga diperoleh 4 lokasi tidak relevan.

Setelah dilakukan analisis hasil perhitungan pemusatan kluster pada masing-masing variabel untuk setiap dataset karakteristik demografi diperoleh informasi mengenai data awal berupa variabel demografi dari setiap karakteristik. Variabel demografi ini dapat digunakan oleh pihak partai politik untuk menentukan sasaran karakteristik pemilih dalam proses kampanye. Sehingga dapat menentukan isu-isu kampanye yang menjadi prioritas untuk disampaikan kepada pemilih di lokasi potensial. Lokasi-lokasi potensial kampanye untuk masing-masing karakteristik dirangkum dalam bentuk tabel yang dapat dilihat pada Tabel 5.

Tabel 5. Rekapitulasi Lokasi Potensial Kampanye

\begin{tabular}{|c|c|c|c|c|c|}
\hline \multirow{2}{*}{ No } & \multirow{2}{*}{ Kelurahan } & \multicolumn{4}{|c|}{ Karakteristik Kependudukan (Demografi) } \\
\hline & & Pekerjaan & Agama & Pendidikan & Usia \\
\hline & \multicolumn{5}{|l|}{ Kec. Cimahi Selatan } \\
\hline 1 & Cibeber & $\sqrt{ }$ & $\sqrt{ }$ & $\sqrt{ }$ & $\sqrt{ }$ \\
\hline 2 & Cibeureum & $\sqrt{ }$ & $\sqrt{ }$ & $\sqrt{ }$ & $\sqrt{ }$ \\
\hline 3 & Leuwigajah & $\sqrt{ }$ & $\sqrt{ }$ & $\sqrt{ }$ & $\sqrt{ }$ \\
\hline 4 & Melong & $\sqrt{ }$ & $\sqrt{ }$ & $\sqrt{ }$ & $\sqrt{ }$ \\
\hline \multirow[t]{2}{*}{5} & Utama & $\sqrt{ }$ & $\sqrt{ }$ & $\sqrt{ }$ & $\sqrt{ }$ \\
\hline & \multicolumn{5}{|l|}{ Kec. Cimahi Tengah } \\
\hline 6 & Baros & $\sqrt{ }$ & $\sqrt{ }$ & $\sqrt{ }$ & $\sqrt{ }$ \\
\hline 7 & Cigugur Tengah & $\sqrt{ }$ & $\sqrt{ }$ & $\sqrt{ }$ & $\sqrt{ }$ \\
\hline 8 & Cimahi & $\sqrt{ }$ & $\sqrt{ }$ & - & - \\
\hline 9 & Karangmekar & $\sqrt{ }$ & $\sqrt{ }$ & - & $\sqrt{ }$ \\
\hline 10 & Padasuka & $\sqrt{ }$ & $\sqrt{ }$ & $\sqrt{ }$ & $\sqrt{ }$ \\
\hline \multirow[t]{2}{*}{11} & Setiamanah & $\sqrt{ }$ & $\sqrt{ }$ & $\sqrt{ }$ & $\sqrt{ }$ \\
\hline & \multicolumn{5}{|l|}{ Kec. Cimahi Utara } \\
\hline 12 & Cibabat & $\sqrt{ }$ & $\sqrt{ }$ & $\sqrt{ }$ & $\sqrt{ }$ \\
\hline 13 & Cipageran & $\sqrt{ }$ & $\sqrt{ }$ & $\sqrt{ }$ & $\sqrt{ }$ \\
\hline 14 & Citeureup & $\sqrt{ }$ & $\sqrt{ }$ & $\sqrt{ }$ & $\sqrt{ }$ \\
\hline 15 & Pasirkaliki & $\sqrt{ }$ & $\sqrt{ }$ & $\sqrt{ }$ & - \\
\hline
\end{tabular}

Tabel 5 menyajikan informasi mengenai lokasi kelurahan setiap kecamatan di Kota Cimahi berupa lokasi potensial dan lokasi tidak potensial dilakukannya kampanye. Penjabaran informasi pada tabel tersebut sebagai berikut:

1) Semua kelurahan di Kota Cimahi berpotensi sebagai lokasi untuk dilakukanya kampanye pilkada.

2) Setiap lokasi potensial kampanye memiliki variabel karakteristik demografi sebagai data awal untuk menyusun isu-isu kampanye yang sangat relevan, relevan, dan tidak relevan.

3) Terdapat 3 lokasi yang kurang potensial untuk dijadikan sebagai lokasi kampanye, yaitu Kelurahan Cimahi, Karangmekar, dan Pasirkaliki.

4) Data awal kampanye berdasarkan karakteristik pekerjaan bersifat potensial di semua kelurahan di Kota Cimahi.

5) Data awal kampanye berdasarkan karakteristik agama bersifat potensial di semua kelurahan di Kota Cimahi.

6) Data awal kampanye berdasarkan karakteristik pendidikan bersifat potensial di kelurahan di Kota Cimahi, kecuali Kelurahan Cimahi dan Karangmekar.

7) Data awal kampanye berdasarkan karakteristik usia bersifat potensial di kelurahan di Kota Cimahi, kecuali Kelurahan Cimahi dan Pasirkaliki. 


\section{KESIMPULAN}

Data karakteristik demografi pada penelitian ini dianalisis menggunakan metode Global Moran's I. Metode ini diterapkan untuk memroses dataset wilayah Kota Cimahi yang berisikan informasi variabel demografis data karakteristik kependudukan pada masingmasing wilayah apakah saling berhubungan satu dengan yang lain. Dengan demikian diketauhi adanya autokorelasi spasial positif dan pola kluster spasial yang terbentuk di wilayah Kota Cimahi. Data demografi pada penelitian ini dimodelkan dengan menggunakan metode Getis-Ord G. Metode ini memroses pola kluster spasial unit area di Kota Cimahi sehingga dapat terbentuk pemusatan nilai-nilai yang tinggi (hot spot) dan rendah (cold spot). Data awal kampanye yang bersifat sangat relevan diperoleh berdasarkan wilayah pemusatan hot spot, relevan diperoleh berdasarkan wilayah yang tidak signifikan dan tidak relevan diperoleh berdasarkan wilayah pemusatan cold spot. Berdasarkan hasil analisis statistika spasial diketahui adanya 3 kelurahan di Kota Cimahi yang kurang potensial dijadikan sebagai lokasi kampanye, yaitu kelurahan Cimahi, Karangmekar, dan Pasirkaliki. Berdasarkan hasil analisis tersebut juga dapat diketahui bahwa di seluruh kelurahan Kota Cimahi, data awal kampanye yang relevan adalah data karakteristik pekerjaan dan agama. Karakteristik pendidikan relevan di seluruh kelurahan Kota Cimahi, kecuali Kelurahan Cimahi dan Karangmekar. Karakteristik usia juga relevan di seluruh kelurahan Kota Cimahi, kecuali Kelurahan Cimahi dan Pasirkaliki.

\section{UCAPAN TERIMA KASIH}

Penulis mengucapkan terima kasih kepada staf PT EFORT Digital Multisolution, selaku pihak yang banyak membantu dalam proses pengumpulan data.

\section{DAFTAR PUSTAKA}

Edwin, D., Chalid, P., Anugrah, P., Wardani, S.B.E., dan Hidayat, S. (2011). Pilkada Langsung: Demokratisasi Daerah dan Mitos Good Governance. Jakarta: Partnership.

Ikhsan, M. (2016). Evaluasi Pelaksanaan Pemilihan Kepala Daerah Secara Langsung di Kabupaten/Kota. Dipetik 10 Februari 2016 dari http://www.stialan.ac.id/artikel/artikel $\% 20 \mathrm{~m} \% 20$ ikhsan.pdf

KPU \& KIPP Kabupaten Sampang. (2015). Analisa Perilaku Pemilih Dalam Memilih Calon atau Peserta Pemilu di Kabupaten Sampang (Studi Kasus Pemilu Legislatif dan Pemilu Presiden Tahun 2014). Dipetik 30 April 2016 dari http://www.kpu.go.id/koleksigambar/ Analisa_Perilaku_Pemilih_Dalam_Memilih_Calon_Atau_Peserta_Pemilu_(KPU_Kabupaten Sampang).pdf.

Republik Indonesia. (2015). Undang-Undang Nomor 8 Tahun 2015 Tentang perubahan atas Undang-Undang Nomor 1 tahun 2015 Tentang Penetapan Peraturan Pemerintah Pengganti Undang-Undang Nomor 1 Tahun 2014 Tentang Pemilihan Gubernur, Bupati, dan Walikota menjadi Undang-Undang.

Soekanto, S. (2007). Sosiologi : Suatu Pengantar. Jakarta. Raja Grafindo Persada. 